\title{
Computed tomography in the diagnosis of steroidal hepatopathy in a dog: case report
}

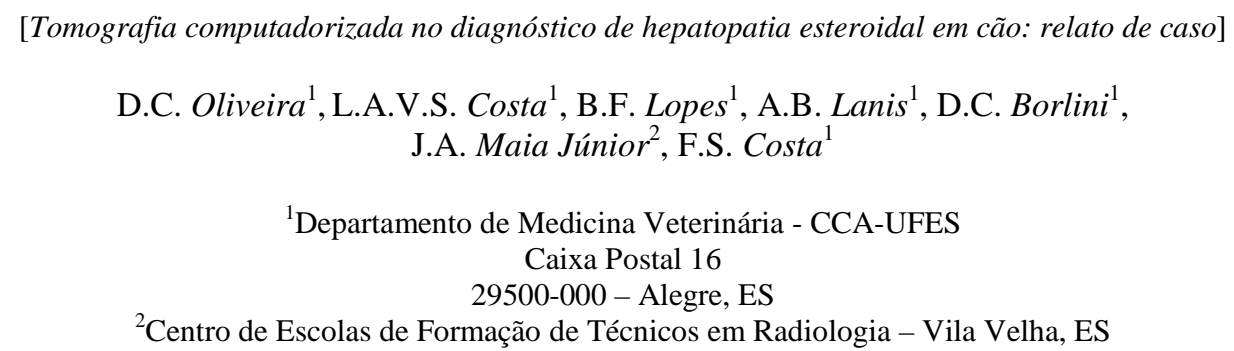

\begin{abstract}
It is reported a case of an eight-year-old Yorkshire Terrier dog, with a history of prolonged use of prednisone in a dosage of $1 \mathrm{mg} / \mathrm{kg}$ of body weight each 24 hours during two years. The helical computed tomography revealed hepatomegaly associated to a hyperattenuation of the parenchyma, with a radiodensity value of 82.55 Hounsfield units (HU). The spleen presented a mean radiodensity of $57.17 \mathrm{HU}$, and a radiodensity difference of $25.38 \mathrm{HU}$ was observed between the two organs. Based on the history and findings of imaging technique, it was determined the presumptive diagnosis of steroidal hepatopathy compatible with accumulation of hepatic glycogen. It was concluded that computed tomography enabled the characterization of hepatic injury and the presumed diagnosis of steroidal hepatopathy.
\end{abstract}

Keywords: dog, helical computed tomography, glycogenosis, steatosis, prednisone

\section{RESUMO}

Relata-se o caso de um cão da raça Yorkshire, de oito anos de idade, com histórico de tratamento com prednisona na dose de $1 \mathrm{mg} / \mathrm{kg}$ de peso, a cada 24 horas, por dois anos. A tomografia computadorizada helicoidal revelou hepatomegalia associada à hiperatenuação, com radiodensidade de 82,55 unidades Hounsfield (HU). O baço apresentava radiodensidade média de 57,17HU, sendo observada diferença de radiodensidade de 25,38HU entre os dois órgãos. Por meio do histórico e dos achados da técnica de imagem, foi possível determinar o diagnóstico presuntivo de hepatopatia esteroidal compatível com acúmulo de glicogênio hepático. Concluiu-se que a tomografia computadorizada possibilitou caracterizar a lesão hepática e presumir o diagnóstico de hepatopatia esteroidal.

Palavras-chave: cão, tomografia computadorizada helicoidal, glicogenose, esteatose, prednisona

\section{INTRODUCTION}

Prednisolone is a synthetic steroid glucocorticoid, with intermediary action, oral biodisponibility of up to $100 \%$, and great antiinflammatory power (Schäcke et al., 2002; Cohn, 2006). It acts on the metabolism of the carbohydrates, increasing the gluconeogenesis with the reduction of the peripheral use of glucose and increase of the glycogen reserves and promoting a significant hyperglycemic effect. In the proteic metabolism, it increases the catabolism and inhibits that anabolism; and in terms of the lipids, it increases the catabolism. About $70 \%$ of the glucocorticoids are metabolized in the liver and its pharmacodynamic characteristics may induce hepatopathies with the deposition of glycogen and/or lipids in the hepatocytes (Lowe et al., 2007).

Glycogenosis promotes an increase in hepatic radiodensity; this fact had already been verified

Recebido em 21 de dezembro de 2009

Aceito em 22 de dezembro de 2010

E-mail:danielcapucho@gmail.com 
in humans (Doppman et al., 1982; Rockall et al., 2003; Tsujimoto et al., 2006) and rats (Leander et al., 2000). According to Doppman et al. (1982), the accumulation of glycogen is the main cause for dense livers in humans. Rockall et al. (2003) carried out in vitro studies and demonstrated that for each increment of $1 \%$ in hepatic glycogen concentration, there is an increase in radiographic attenuation coefficient from 2.5 to $3.0 \mathrm{HU}$ at the tomographic exam.

In veterinary medicine, computed tomography (CT) is a current imaging method in full expansion. This exam presents ample indications for cats and dogs, and is an important tool for the establishment of countless diagnoses on a daily basis (Smallwood and George, 1993; Winter et al., 2005; Ohlerth and Sharf, 2007). The literature demonstrates that the CT can be used in humans for the differential diagnosis of accumulation of hepatic glycogen and steatosis, since it is a precise and minimally invasive technique (Rockall et al., 2003).

This study aimed to describe the case of a dog with increased abdominal volume, with clinical suspicion of hepatic neoplasia and tomographic presumptive diagnosis of steroidal hepatopathy, demonstrating the importance of this imaging technique for the diagnosis of hepatic injuries.

\section{CASE DESCRIPTION}

An eight-year-old male Yorkshire Terrier dog, was referred for a tomographic exam in order to evaluate its abdominal cavity with a suspected case of hepatic neoplasia. The clinical examination revealed an increase in the abdominal volume, hepatomegaly, and elevation of the serum levels of the ALT, AST, GGT, and FA enzymes. According to the owner, due to dermatological problems, the animal was given the corticoid prednisone (Meticorten, Forma Farmacêutica, Brazil) each 24 hours, for approximately two years in doses of $1 \mathrm{mg} / \mathrm{kg}$ of body weight.

In order to perform the computed tomography exam, the dog was submitted to alimentary abstinence for 12 hours. Pre-anesthetic medication, diazepam $(0.5 \mathrm{mg} / \mathrm{kg})$, was intravenously administered and general anesthesia was intravenously induced and maintained with propofol $(6 \mathrm{mg} / \mathrm{kg})$. During the procedure, fluid therapy was applied with physiological solution ( $\mathrm{NaCl} 0.9 \%$ ), serving as access for the administering of the drugs used. The animal was positioned in right lateral recumbence. The capturing of tomographic images was done by a helical tomograph (General Electric Medical Systems, Hi-Speed FX/i CT Scanner) with $120 \mathrm{kVp}$ and auto-mA, at a speed of 1 rotation/s. Cross sections with $2 \mathrm{~mm}$ of thickness were made, obtained from the diaphragmatic dome to the iliac crests. A soft part filter was used and the equipment was properly calibrated before the capturing of the images. After the tomographic exam and the digitalization of the images, an evaluation of the liver and related structures was performed.

The subjective evaluation of the images allowed the verification that, despite the significant hepatomegaly, there were no images compatible with neoplastic processes or other focal alterations involving the liver and other organs in the abdominal cavity. It was opted for the evaluation of the radiodensity of the hepatic parenchyma in order to investigate possible alterations resulting from the corticotherapy.

According to the methodology described in humans by Kodama et al. (2007) and adapted to dogs by Costa et al. (2010), X-ray attenuation degree was calculated from the mean value of three regions of interest (ROI) in hepatic parenchyma and one ROI in the spleen, following three representative levels. The levels for the evaluation of the hepatic and splenic radiodensity were selected in three different slices of the organs. For the liver, the ROI of the left lateral lobe, the right lateral lobe, and the square lobe were selected (Figure 1), and for the spleen, the measurement in the region of its largest volume was selected (Figure 2).

The results demonstrated that the mean radiodensity of hepatic parenchyma in the evaluated regions was of $82.55 \mathrm{HU}$. The spleen presented a mean radiodensity of $57.17 \mathrm{HU}$, and a radiodensity difference of $25.38 \mathrm{HU}$ was observed between the two organs. Thus, an elevated radiodensity of the liver was characterized in the tomographic exam suggesting the diagnosis of hepatic glycogen accumulation above normal levels (glycogenosis). 


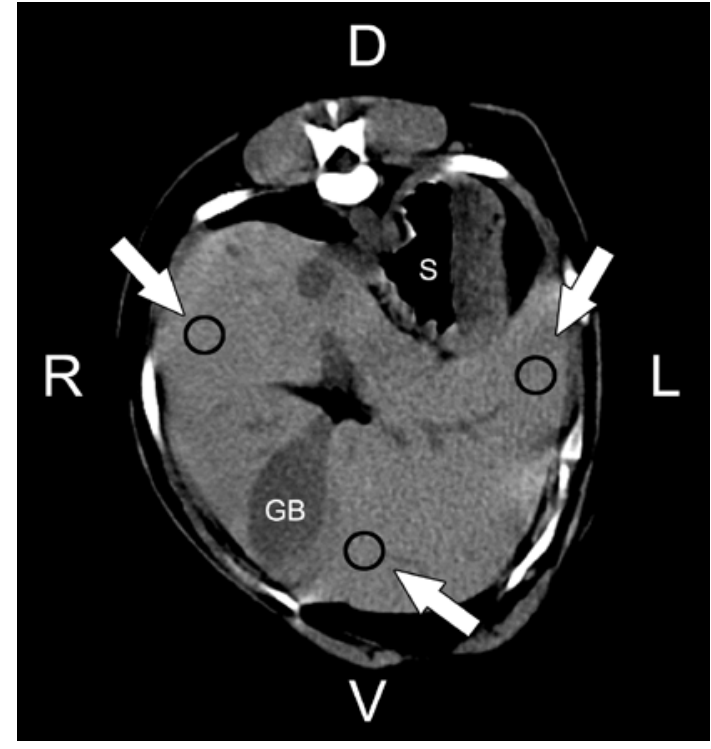

Figure 1. Transverse computed tomography image of the abdomen of an eight-year-old male Yorkshire Terrier dog submitted to a long-term therapy with prednisone, demonstrating the selection of the regions of interest (black circles indicated by the white arrows) in order to measure the hepatic radiodensity. D, dorsal; V, ventral; R, right; L, left; S, stomach; GB, gall bladder.

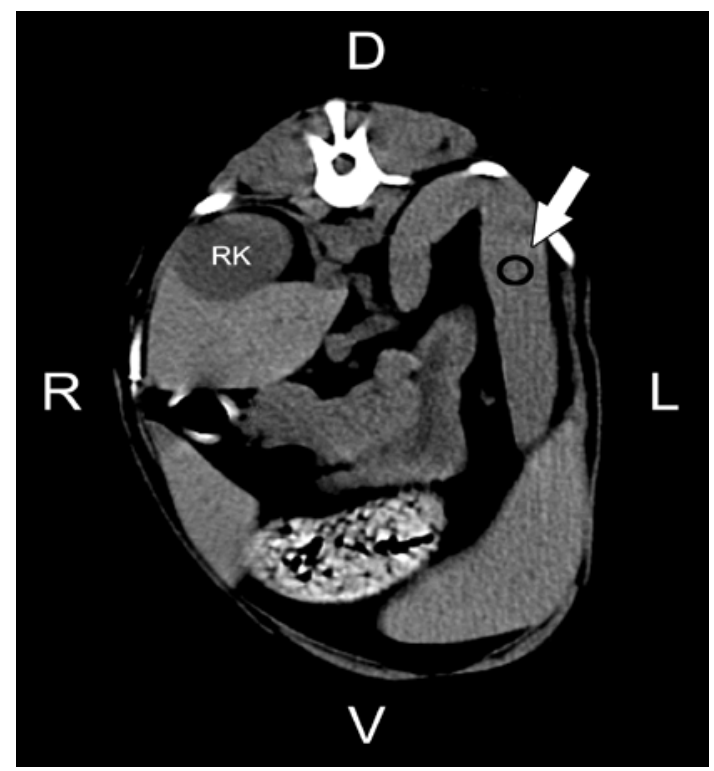

Figure 2. Transverse computed tomography image of the abdomen of an eight-year-old male Yorkshire Terrier dog submitted to a long-term therapy with prednisone, demonstrating the selection of the region of interest (black circle indicated by the white arrow) in order to measure the splenic radiodensity. D, dorsal; V, ventral; R, right; L, left; RK, right kidney.

\section{DISCUSSION}

Few studies state normal radiodensity values for hepatic parenchyma in dogs. Costa et al. (2010), using the same methodology described in this article, determined hepatic parenchyma radiodensity values in eight healthy dogs. The mean value of radiographic attenuation was 59.58 $\pm 3.34 H U$. Ohlerth and Scharf (2007) stated that the liver of normal dogs must present a radiodensity from 50 to $70 \mathrm{HU}$. Cáceres et al. (2006) found mean value of 65HU of x-radiation attenuation in the liver of $65 \mathrm{HU}$ in five normal dogs, with the values ranging from 60 to $70 \mathrm{HU}$. In the present report, an elevated radiodensity was characterized when compared to the values of normality described in the consulted literature.

In this case, it was observed that the liver was significantly hyperattenuated in comparison to the spleen, presenting a difference of $25.38 \mathrm{HU}$. According to Kodama et al. (2007), in humans, a comparative evaluation of radiographic attenuation degree between these organs is of great importance for a better elucidation of the process, as in normal patients, the liver is hyperattenuated in comparison to the spleen. It was observed that in healthy patients, the liver presented an approximately 3HU higher radiodensity than the spleen. In dogs, experimental studies (Costa et al., 2010) demonstrated that this fact is repeated, with hepatic parenchyma presenting a $4 \mathrm{HU}$ higher radiodensity in comparison to splenic parenchyma.

It was possible to discard the occurrence of hepatic steatosis in the present case, since all the evaluated regions presented radiodensity values superior to those considered as normal for dogs. According to Nakamura et al. (2005), the CT in animals, as well as verified in humans, allows the diagnosis of hepatic steatosis in a less invasive manner when compared to biopsy, laparotomy, and laparoscopy techniques. The authors verified a significant reduction of the hepatic radiodensity in cats with lipidosis in comparison to the control group.

It must be emphasized in this case that, in order to determine hepatic parenchyma radiodensity, the use of intravenous contrast was not performed. According to Doyon et al. (2004), despite the favoring of the identification of the 
vascular structures, the radiographic contrast interferes directly in its radiodensity, providing an unreal result.

\section{CONCLUSIONS}

Based on the helical computed tomography findings, it was possible to correlate the clinical signs and the laboratorial alterations to a profile of steroidal hepatopathy with an accumulation of hepatic glycogen. The computed tomography enabled the characterization of hepatic injury and the presumed diagnosis of steroidal hepatopathy.

\section{REFERENCES}

CÁCERES, A.V.; ZWINGENBERGER, A.L.; HARDAM, E. et al. Helical computed tomographic angiography of the normal canine pancreas. Vet. Radiol. Ultrasound, v.47, p.270278, 2006.

COHN, L.A. Glucocorticoid therapy. In: ETTINGER, S.J.; FELDMAN, E.C. (Eds). Textbook of veterinary internal medicine. 6.ed. St. Louis: Elsevier Saunders, 2006. p.503-508.

COSTA, L.A.V.S.; MAESTRI, L.F.P.; MAIA JÚNIOR, J.A. et al. Radiodensidade hepática de cães hígidos por tomografia computadorizada helicoidal. Cienc. Rural, v.40, p.888-893, 2010.

DOYON, D.; CABANIS, E.A.; FRIJA, J. et al. (Eds). Tomografia computadorizada. 2.ed. Rio de Janeiro: MEDSI, 2004. 392p.

DOPPMAN, J.L.; CORNBLATH, M.; DWYER, A.J.J. et al. Computed tomography of the liver and kidneys in glycogen storage disease. $J$. Comput. Assist. Tomo., v.6, p.67-71, 1982.

KODAMA, Y.; NG, C.S.; WU, T.T. et al. Comparison of CT methods for determining the fat content of the liver. Am. J. Roentgenol., v.188, p.1307-1321, 2007.
LEANDER, P.; MANSSON, S.; PETTERSSON, G. Glycogen content in rat liver. Acta Radiol., v.41, p.92-96, 2000.

LOWE, A.D.; GRAVES, T.K.; CAMPBELL, K.L. et al. A comparison of the diabetogenic effects of dexamethasone and prednisolone in cats. Vet. Dermatol., v.18, p.184, 2007.

NAKAMURA, M.; CHEN, H.M.; MOMOI, Y. et al. Clinical application of computed tomography for the diagnosis of feline hepatic lipidosis. J. Vet. Med. Sci., v.67, p.1163-1165, 2005.

OHLERTH, S.; SHARF, G. Computed tomography in small animals: Basic principles and state of the art applications. Vet. J., v.173, p.254-271, 2007.

ROCKALL, A.G.; SOHAIB, S.A.; EVANS, D. et al. Hepatic steatosis in Cushing's syndrome: a radiological assessment using computed tomography. Eur. J. Endocrinol., v.149, p.543548, 2003.

SCHÄCKE, H.; DÖCKE, W.D.; ASADULLAH, $\mathrm{K}$. Mechanisms involved in the side effects of glucocorticoids. Pharmacol. Therap., v.96, p.2343, 2002.

SMALLWOOD, J.E.; GEORGE II, T.F. Anatomic atlas for computed tomography in the mesaticephalic dog: Thorax and cranial abdomen. Vet. Radiol. Ultrasound, v.34, p.65-84, 1993.

TSUJIMOTO, T.; TAKANO, M.; NISHIOFUKU, $M$. et al. Rapid onset of glycogen storage hepatomegaly in a type-2 diabetic patient after a massive dose of longacting insulin and large doses of glucose. Intern. Med., p.469-473, 2006.

WINTER, M.D.; KINNEY, L.M.; KLEINE, L.J. Three-dimensional helical computed tomographic angiography of the liver in five dogs. Vet. Radiol. Ultrasound, v.46, p.494-499, 2005. 